\title{
Islam and the Western Philosophy of Knowledge
}

By Muhammad Mumtaz Ali. Selangor, Malaysia: Pelanduk Publications, 1994, $103 \mathrm{pp}$.

It is a simple truism to state that any scholar who treats such a vast topic as "Islam and the Western Philosophy of Knowledge" must be familiar with the different domains of intellectual and philosophical discourses in bvth the Muslim and the western worlds, their epistemological bases (i.e., foundational conceputal principles), historical evolution, and cultural expressions. In addition, such a scholar cannot do justice to this important topic without constructing an appropriate and comprehensive comparative method that might shed some light on why there have been some important divergences between the Muslim worldview and the western one, especially in the modern period (e.g., the past few centuries). Third, in dealing with the above subject, a scholar must know at least one Islamic language (e.g., Arabic) and one European language in addition to English (e.g., French or German). Measured against this criteria, the author of this (very) tiny work fails miserably to justify his goal(s) for writing this book, to offer a convincing method of comparative analysis, and to prove that he possesses the appropiate tools (i.e., sources and languages) with which to conduct his research.

To begin with, the author states in the Preface that he intends to offer "a humble contribution to the contemporary debate on the need for a new episte- 
mology." The nature of the contemporary debate the author refers to is unclear: Is it an Islamic debate? Western or African? Second, what is the nature of this new epistemology of which he speaks? His entire discussion throughout the book does not mention any new epistemology per se, but rather a historically old and established one: that of the Qur'an and other revelations. So, is the author offering a Qur'anic rationale for and justification of some criucial philosophical issues arising in the modern western world, or is he interested in measuring the impact of western philosophy on the modern Muslim mind in the context of colonialism and the new world order? No such desire is expressed. When the author states in his Acknowledgment that "I came to the conclusion that the real malaise of the Muslim Umma is the intellectual," he does not tell us why it is so and why it is not economic, political, social, or a combination of the above.

In the first chapter, "Some Primordial Philosophical Issues," Ali pins down what he terms "some fundamental and primordial philosophical issues" and determines that they revolve around the following: First, the Creator; second, knowledge; and third, truth or reality (p. 3). The Creator, he states, is the key to all of our questions, including knowledge and truth. However, knowledge and truth are divinely inspired and metaphysically bound. One can infer just that from the author's arguments. These issues fall under the category of religious belief, not philosophical cognition. And here is the difference between philosophy and "theology," if we are to use the latter term to refer to Islamic religious thought. Philosophy is a reflection of the deep alienation of humanity from life and the eternal quest, whereas theology is a measure of humanity's deep commitment to the divine and the eternal quest. The philosopher, in the words of Hegel's Lectures on Religion, is always alienated because he/she always raises new questions. On the other hand, the theologian is committed to divine principles and he/she is always obsessed with the divine, or what Paul Tillich terms "ecstatic reason."

The author's discussion leads him to state, albeit ambiguously, that the Qur'an, as the main source of Islamic (religious) knowledge, is about philosophical questions. But if the Qur'an holds the key to such metaphysical questions as the origin of the universe and the Creator, how does the author reconcile his philosophical arguments with the metaphysical ones? The philosophical and metaphysical are two somewhat different domains of argument and are based on two separate sets of premises that have proven to be contradictory throughout human history. In other words, the author confuses, analytically speaking, issues of religious belief with those of cognitive philosophy. This confusion is not bad in itself. Was not "confusion" the crux of the extensive philosophical debates in early Islam between the Ash'arites and the Mu'tazilites, to which the author does not refer at all? What lessons might a modern Muslim thinker and philosopher learn from these great debates in early Islam, and are they still relevant to the current situation of the Muslim world?

During the emergence of the West as the dominant power, or conglomeration of powers, especially in the wake of the Industrial Revolution, many a western thinker and philosopher started to think of the West in primary and central terms and of the nonwestern world in marginal terms. Such terms as "Europe and the people of other histories" and "the Christian world versus the non-Christian one" exemplify the deep historical bias against the other non-European people, many of whom came to be dominated and colonized by the West for many years. In the process of colonization, European powers always presented their weltan- 
schauung as the most central and relevant to modern world history. This elitist attitude, of course, was refuted by many leading Third World intellectuals, such as Paulo Friere (The Pedagogy of the Oppressed), 'Alı Shari'āi (On the Sociology of Islam), Sayyid Qutb (The Battle between Islam and Capitalism), Franz Fanon (The Wretched of the Earth), Anwār 'Abd al-Mālik (Dirāsāt fi al-Thaqäfah alWataniyah), Hichem Djait (Islam and the West: Cultures and Modernity), Muhammad al-Ghazā̄i (Al-Isti'mār: Ahqād wa Atmā̄t), and Muhammad Aziz Lahbabi (Le Monde de demain: Le Tiers-Monde accusé).

What is disturbing, however, is that there are some other leading Third World and Muslim intellectuals and thinkers who accept the notion that the West and western civilization are the measure of any real progress and that the "others" can only imitate the West because they are incapable, allegedly, of producing original ideas. This erroneous notion has seeped into the consciousness of some of the best Muslim intellectuals, who equate "modern" with "European" and "western" and who tend to forget-and embarassingly sothat the Third World, in general, and the Muslim world, in particular, are permeated with all sorts of ideas and philosophies that reflect the depth and uniqueness of the issues and questions the Muslim world faces. The modern Muslim mind, for example, has been struggling with such issues as colonialism, political and intellectual independence, the role of religion in the political and social processes, women's and minorities' issues and concerns, and relations to the West in general. These are not marginal issues, although many political forces, both domestic and international, have always attempted to marginalize the concerns of the Muslim world and its leading intellectuals.

The author falls into the same error: He equates the modern world with the West and philosophy with western philosophy. What about modern philosophy in India, Latin America, or the Muslim world? There are leading philosophers in all of these places; the author seems unaware of them. Following the author's logic, he discusses in chapter 2, "The Methodology of Philosophy," what he terms the limitations of modern western methodology and philosophy, beginning with Plato (discussed in less than one page), and then jumps to such twentieth-century philosophers as Walter Stace, William James, and Wilhelm Dilthy. Ali does not tell us why he selects these particular philosophers, and why, for instance, he does not select Bertrand Russell, Karl Popper, and Richard Rorty. His only conclusion is that rational philosophical inquiries fail to delve into metaphysical reality, a conclusion that seems to contradict one of his main premises: Philosophical inquiry is the source of the eternal and primordial quest and concern.

Looking at chapter 3, "The Methodological Issues: A Critique," one realizes that the author takes up the same issues as in the preceding chapter only to deal with another set of western philosophers: René Descartes, Immanuel Kant, John Dewey, and Walter Stace (for the second time). One might expect that, in this chapter, the author will offer new insights, conclusions, and ideas. However, he only repeats his assertion that western philosophy is bereft of metaphysical answers, because of its rationalism and empiricism, and goes on to argue that "All the questions begins and ends [sic] with the same question on reality" [sic] (p. 67). The author spends most of his time trying to convince the reader that the philosophical method, as it has evolved in the western world, does not hold the key, so to speak, to the mystery of the universe and then accepts a totally contradictory premise. 
At the end of the book, the author comes to what strikes the reader as a sudden conclusion: His work belongs to the tradition of the Islamization of knowledge spearheaded by the late Ismāill al-Fāñ̄ī, Syed Muhammad Naquib al-Attas, and Țāhā al-'Alwāñ. However, he does not discuss any of them in any significant fashion (the only one he refers to superficially is al-Attas, on page 73). If this book belongs to the Islamization of knowledge school, why does the author not say so at the outset? Why does he not ground his theories in this tradition of contemporary Islamic thinking?

In addition to the above theoretical flaws, the book also suffers from a mass of technical problems, especially in relation to language and style. It is unfortunate that the publisher published a book in English without a proper copyediting of the text.

Ibrahim M. Abu-Rabi' Hartford Seminary Hartord, Connecticut 